\title{
Comprehensive model of business intelligence: A case study of Nano's companies
}

Vol. 5 No. 6 (June 2012) ISSN: 0974-6846

\author{
Hosseini Mirza Hasan, Forozandeh Lotfollah and Motamedi Negar,
}

\author{
Business administration of Payam Noor University, Iran, Tehran \\ Ir_hosseini@yahoo.com; I.forozandeh@gmail.com; Motamedi@phd.pnu.ac.ir*
}

\begin{abstract}
The implementation of business intelligence $(\mathrm{BI})$ system is a complicated undertaking requiring considerable resources. This research tries to identify the critical success factors that affect the Business intelligence Implementation. The study develops a CSF's framework crucial for BI systems implementation. Next, the framework and the associated CSF's are delineated through a series of NANO's Organization. The empirical findings demonstrate the construct and applicability of the frame work. This study from the aiming view point is practical and from method of data collection and analysis view point is descriptive and is of correlative type. The model of the research has two parts that includes: Critical success factors of business intelligence and system success. Through this model, eight hypotheses were developed that six of them were confirmed. Base on the results of this research, it is recommended that Nano's companies must empower their information technology capacity to have better chance to be the winner of the competitive world.
\end{abstract}

Keywords: Business intelligence system, Critical success Factors, NANO `s Industry

Introduction

Davenport et al. (2007) argued that $\mathrm{BI}$ is a set of technologies and processes that use data to understand and analyze organization performance and includes using of information to stimulate business insight (Platon, 2009). In another words, $\mathrm{BI}$ is an interactive process for exploring and analyzing structured, domain-specific information (often stored in a data warehouse) to discern trends or patterns, thereby deriving insights and drawing conclusions in organization (Markarian et al., 2007).

With developing technology in particular IT, many researchers understood the importance of $\mathrm{BI}$ as an inseparable part of new businesses, which can link strategic objectives and operational goals in each organization. For example, Salegro et al (2008) investigated the applications of business intelligence systems in personalizing tourism services or Nadeem et al. (2003) did a research, with regarding to the applications of business intelligence systems in Pakistan's banks and Sharaki and Esmaeeil poor (2010) used a business intelligence-based system in order to support sugar markets in Iran. These studies show emerging the demand for using $\mathrm{BI}$ in organizations to enhance IT-based systems of business towards new patterns of knowledge management, which it is the main aim of developing $\mathrm{BI}$ in organizations. It means that organizations try to access to newest market information without spending huge expenses. Is it an inaccessible dream? The answer to this question has in fact been hidden at concept of $\mathrm{BI}$.

Furthermore, various researches have been done to explore the critical success factors of business intelligence. Vodappalli (2009) determined the key success factors of business intelligence through three dimensions: organization, technology, process. In other investigation, Olszak and Ziemba (2003) developed four dimensions: Organization, function, technology and business as the effective factors on $\mathrm{BI}$.

In this paper, researchers introduce the critical success factors of business intelligence systems in Nano's companies in IRAN. To do this, in the first place, research variables would be placed in a conceptual model of business intelligence. This model is analyzed by using structural equation modeling to show that the factors determined have well been located. As for this, researchers try to identify critical success factors of business intelligence in form of a comprehensive model and with providing eight hypotheses designed which describe the role of $\mathrm{BI}$ in achievement of organizational systems. Thereafter, it would be discussed the hypotheses rejection and confirmation. Finally, the result of the research would be concluded by providing essential solutions for improving the organizational systems. In another word, in this case, the researchers try to answer these questions: What are the critical success factors of business intelligence system implementation in NANO technologies area in Iran? What are the challenges of business intelligence implementation in NANO's companies in Iran? What are the requirements of business intelligence system implementation in NANO's companies?

So it can be said that the strength of this research is reviewing of the new resources and combination and incorporation of existing model and developing the new frame of BI factors and system success in NANO's area. It is noteworthy that no similar research has been done in this era in Iran.

\section{Critical success factors}

According to Saraph et al (1989) CSFs consists of critical areas of managerial planning and action that must be practiced in order to achieve effectiveness. He added that they are a broad range of factors which can be effective on the success of $\mathrm{Bl}$ implementation mentioned
Research article

Clndian Society for Education and Environment (iSee)
"Business intelligence"

http://www.indjst.org
M.Negar et al. Indian J.Sci.Technol. 
in the literature. For example, Yeoh (2011) developed a framework of critical success factors of BI system which are divided to three dimensions: Organization, including factors based on vision \& business and also management \& championship, Process which includes team -based factors, project management and methodology-related factors, change management-related factors, Technology which contains data-related factors and infrastructurebased factors.

Moreover, Rud (2009) specified 5 factors in his book, called under title: "Business Intelligence Success Factors". Effective communication, Collaboration, Innovation, Adaptability, Leadership were factors which Rud determined them as CSFs in IB.

As it was mentioned before, numerous studies have been done around the critical success factors of Data Warehouse, Data Mining, ERP and Knowledge Management as the information-based technologies which have high convergence towards $\mathrm{BI}$ systems. In this case, Xu and Hwang (2008) identified Operational, Technical, Economic, Schedule factors as the critical success factors of data warehouse. These factors were studied by a systematic approach to system quality and information quality and were concluded in individual and organizational contexts. In another research by Valmohammadi (2010), discussed about critical success factors of Knowledge management as follows: management leadership and support, organizational culture, information technology, KM strategy, performance measurement, organizational infrastructure, process \& activities, rewarding \& motivation, training \& education, removal or resource constraints, human resource management, benchmarking. These components show a common link between organization, knowledge gained from markets and BI. Study of various researches describes that IB can be caused of different variables, shown in the Table 1.

\section{System success}

Researchers have investigated the success of information technologies as DW, DM, BI, KM in myriad ways (Garrity \& sanders, 1998 ) such as by measuring the satisfaction of users (Melone, 1990), service quality (Pitt et al., 1995) and the perceived usefulness of specific applications (Davis, 1989;Moore \& Benbasat,1991).Or in another study Abu Ali and Abu Addose (2010) developed a framework to describe the system success by easy to use, speedy information retrieval, more information, better quality information, improved productivity, better decision for data warehouse and Watson and Ariyachandra (2005) stated the accuracy, completeness, consistency, flexibility, integration, scalability, individual impact, organizational impact, development time and cost as the measures of system success.

So by reviewing the literature, we categorized these measures as follows in two dimensions: Improved productivity that would be measured by effectiveness improvement, efficiency improvement, improvement of system's performance. Improved decision making that would be measured by data validity, data accessibility and processing capacity of data.

Hence, in this study, research framework consists of two parts: CSFs of business intelligence and system success, measured by 8 hypotheses which is shown in figure 1:

$\mathrm{H} 1$ : Human force factor is effective on improvement of productivity

$\mathrm{H}$ 2: Human force factor is effective on improvement of decision making

H3: IT factor is effective on improvement of productivity H4: IT factor is effective on improvement of decision making

H5: Organizational factor is effective on improvement of productivity

H6: Organizational factor is effective on improvement of decision making

$\mathrm{H} 7$ : Environmental factor is effective on improvement of productivity

H8 : Environmental factor is effective on improvement of decision making

\section{Methodology}

This study because of dealing with identifying the critical success factors of business intelligence system in NANO's companies, and developing practical knowledge about relations of these CSF's and system success, from the aiming view point is practical and from method of data collection and analysis view point is descriptive and is of correlative type (Kumar, 2005; Yin, 2003a).

\section{Data collection and analysis}

The Questionnaire comprised 2 different sections. The questions of the first section have been used 3 questions are related to personal information of the respondents. The second section contains 84 statements measuring the 4 Success factors: human force factors, IT factors, Organizational factors, Environmental factors and 2 system success measures: Improvement of productivity and improvement of decision making. Respondent were asked to indicate their extent of agreement using a five point likert scale (with $5=$ completely agree, to $1=$ completely disagree). For analyzing data derived from questionnaire Structural Equation Modeling / Path Diagram has been used and the software's which have been used for analyzing the data are LISREL 8.54 and SPSS 17.

\section{Reliability and validity}

For determining reliability of the study Cronbach's Alpha method has been used. Table 2 shows reliability of the study. For determining validity of the questionnaire content credit has been used (Kumar, 2005; Yin, 2003). Content credit of this questionnaire has been justified by guide professors and co-guides and also initial distribution of questionnaire among number of experts, scholars and considering their corrective comments, it has the necessary credibility.
Research article

Clndian Society for Education and Environment (iSee)
"Business intelligence" http://www.indjst.org
M.Negar et al. Indian J.Sci.Technol. 
Table 1. The list of dimension and authors of critical success factors

\begin{tabular}{|c|c|c|}
\hline Dimension & Description & Authors \\
\hline \multicolumn{3}{|c|}{ Human Factors } \\
\hline 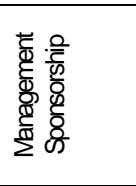 & $\begin{array}{l}\text { Commitment and Sponsorship of management are the first CSF of Business Intelligence. } \\
\text { Yeoh (2011) addressed that management Commitment often happens in two forms: } \\
\text { Management Involvement in steering committees to oversee high - level architecture design, } \\
\text { and Management Involvement in amending organizational structure and / or roles and } \\
\text { responsibilities. }\end{array}$ & $\begin{array}{l}\text { Yeoh (2008), Yeoh (2011), Parr Rud (2009), Howson (2008), AbuAli et al. } \\
\text { (2010), Arnott (2008), Bhatti (2005), Vodappalli (2009), Murray (2009), } \\
\text { ESCC (2009), Dehenry (2009), Knightsbridge (2006), Schwechel (2005), } \\
\text { Briggs (2002), Watson \& Haley (1997), Wixom \& Watson (2001), Arnott \& } \\
\text { Pervan (2005), Dess \& pickens (2000), Ryan and Prybutok (2001), Moffett et } \\
\text { al. (2003) }\end{array}$ \\
\hline 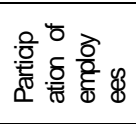 & $\begin{array}{l}\text { Reviewing the literature delineated that Greater User Participation can Contribute to better } \\
\text { appreciation of their needs. Regular workshops and meeting between user and project teams } \\
\text { are an efficient way to achieve organizational objectives (Yeoh, 2011) }\end{array}$ & $\begin{array}{l}\text { Yeoh (2008), Yeoh (2011), Eckerson (2005), Murray (2009), Inet Soft Tech } \\
\text { (2007), ESCC (2009), Knightbridge (2006), Bhatti (2003), Schwechel } \\
\text { (2005), AbuAli et al. (2010), Briggs (2002), Ryan and Prybutok (2001), } \\
\text { Moffett et al. (2003) }\end{array}$ \\
\hline 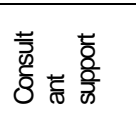 & $\begin{array}{l}\text { Yeoh (2011) addressed that the use of consultants greatly enhanced the success of the } \\
\text { system implementation. A balanced BI team should comprise a quality consultant who } \\
\text { possesses adequate business knowledge and project teams that consist of both business } \\
\text { and technical personnel. }\end{array}$ & $\begin{array}{l}\text { Yeoh (2008), Yeoh (2011), Howson (2006), Howson (2008), Williams \& } \\
\text { Williams (2007), Vodappali (2009), Knightbridge (2006), Schwechel (2005), } \\
\text { Bhatti (2003) }\end{array}$ \\
\hline \multicolumn{3}{|c|}{ (2) } \\
\hline 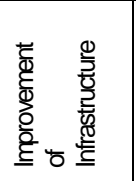 & $\begin{array}{l}\text { A majority of business managers believe in the powers of computers and communication } \\
\text { technologies that lead } \mathrm{BI} \text { implementation success in organizations. So for the success of } \mathrm{BI} \\
\text { system, organizations need many tools and requirements as the software applications, } \\
\text { hardware devices and tools for identifying and preparation of data, designing and performing } \\
\text { and using of } \mathrm{Bl} \text { systems (Tocan, 2009). }\end{array}$ & $\begin{array}{l}\text { Davenport et al. (2007),Yeoh (2008), Yeoh (2011), Dehenry (2009), Hayen } \\
\text { (2007), Vodappalli (2009), Vesset (2005), Mano (2009), Meister (2009), } \\
\text { Knightbridge (2006), Arnott (2008), Bhatti (2003), AbuAli et al. (2010), Briggs } \\
\text { (2002), Ryan and Prybutok (2001), lee and Hong (2002), Paiva et al. (2002), } \\
\text { Wang (2002), Moffett et al. (2003) }\end{array}$ \\
\hline 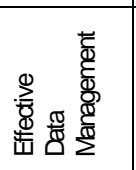 & $\begin{array}{l}\text { A Primary purpose of BI systems is to integrate silos of data for advanced analysis. So as to } \\
\text { improve the decision - making process. Corporate Data can only be fully integrated and } \\
\text { exploited for greater business value once their quality and integrity are assured. Therefore } \\
\text { Effective Data Management plays critical role for success of Bl system (Yeoh, 2010) }\end{array}$ & $\begin{array}{l}\text { Yeoh (2008), Yeoh (2011), ESCC (2009),Vodappalli(2009), NeilmcMurchy } \\
\text { (2008), Dehenry (2009), Makarian et al. (2007), Meister (2009), Schwechel } \\
\text { (2005), Arontt (2008), Manfeld (2006), Briggs (2002) }\end{array}$ \\
\hline 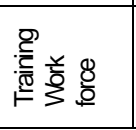 & $\begin{array}{l}\text { Training provides skills and information for employees and managers to fulfill their } \\
\text { responsibilities. Improved performance is a strategic goal for organizations in order to achieve } \\
\text { the bottom line purpose through training and development. For the same reason, a number of } \\
\text { organizations are striving to become learning organizations. }\end{array}$ & $\begin{array}{l}\text { Knightbridge (2006),Bhatti (2003), Vodappalli (2009), Tocan (2009), Moffett } \\
\text { et al. (2003) }\end{array}$ \\
\hline \multicolumn{3}{|c|}{ Organizational Factors } \\
\hline 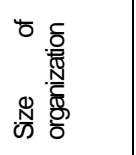 & $\begin{array}{l}\text { Organization size has often been viewed as a predictor of the adoption of administrative } \\
\text { innovations, including computerization or information system use. Increasing size is said either } \\
\text { to necessitate IS use to solve communications and integration problems which arise from } \\
\text { increasing size or at least to facilitate such use by providing greater opportunity to achieve } \\
\text { benefits through organizations (Gremillion, 1984). }\end{array}$ & $\begin{array}{l}\text { Gremillion (1984), Al-hudhaif (2010), Ellis and Webster (1998), Lawler } \\
\text { (1999), Sayal et al. } \\
\text { (2000) }\end{array}$ \\
\hline 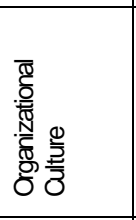 & $\begin{array}{l}\text { An organization's culture refers to the shared beliefs, values, and perception of organization } \\
\text { members about a system practices and procedures (Schneider, 1975). Organization culture } \\
\text { governs the conduct of people and how the organization operates, for example, in terms of } \\
\text { language of communication, work efficiency, meaning of authority, hierarchy and managerial } \\
\text { power, strategic change, creation and utilization of knowledge (Indeje \& Zheng, 2010). }\end{array}$ & $\begin{array}{l}\text { Skyrme and Amidon (1997), Davenport et al. (2007), Liebowitz (1999), } \\
\text { (APQC, 1999), McDermott (2001), Hassanali (2002), ), Wong and Aspinwall } \\
\text { (2005), Al Busaidi (2005), Hung et al. (2005), Akhavan et al. (2006), } \\
\text { Akhavan et al. (2010), Chong(2006), Bozbura (2007), du Plessis (2007), } \\
\text { Vodappalli (2009), Briggs (2002), Valmohammadi (2010), Indeje and Zheng } \\
\text { (2010), Kumarasinghe et al. (2003), Greco (1999), Ryan and prybutok } \\
\text { (2001), Wild et al. (2002), Moffett et al. (2003) }\end{array}$ \\
\hline 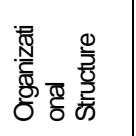 & $\begin{array}{l}\text { Organizational structure explain the relation between individuals and groups those are trying to } \\
\text { achieve organizational goals. In order to study the structure of organization, three dimensions } \\
\text { must be pursued that are: Centralization (the point decisions are made), Formality (the degree } \\
\text { and extent of regulation in organization) and Complexity (the degree of separation). }\end{array}$ & $\begin{array}{l}\text { Hayen (2007), Zannetos and Sertel (1970), Hassanali (2002), Chang and } \\
\text { Harrington (2000), Akhavan and et al. (2010),Reimann (1974), } \\
\text { Yarmohammadzadeh p et al (2011), Kumarasinghe et al. (2003), Buckman } \\
\text { (1999), Hsieh et al. (2002), } \quad \text { Moffett et al. (2003) }\end{array}$ \\
\hline \multicolumn{3}{|c|}{ Environmental Factors } \\
\hline 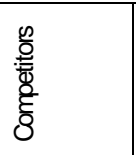 & $\begin{array}{l}\text { Apart from the advantages of business intelligence systems, lack of attention to cost and } \\
\text { infrastructure and requirements of Bl systems and blind imitation of competitors can lead to } \\
\text { irreparable loss for the organization. So the choice of business intelligence system must } \\
\text { consider the benefits and costs of implementation of this information technology. }\end{array}$ & $\begin{array}{l}\text { Drew (1997), O'Dell and Grayson (1998), Day and Wendler (1998), Moffet et } \\
\text { al. (2003), Hung et al. (2005), Chong (2006) Akhavan et al. (2006), OCS } \\
\text { (2003) }\end{array}$ \\
\hline 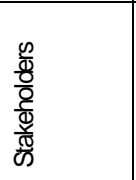 & $\begin{array}{l}\text { Stakeholders are any individual or group that may affect or may be affected by the company's } \\
\text { activities. They have the ability to influence the success or failure of the business at various } \\
\text { levels (e.g. affecting the company's license to operate, eroding levels of trust of the company } \\
\text { etc ). In this framework researchers considered stakeholder as the group that may be affected } \\
\text { by business intelligence system like customer, buyer, supplier, employee, publics. }\end{array}$ & Yeoh (2011), Katsoulakos \& Katsoulacos (2007), Simmers (2004) \\
\hline 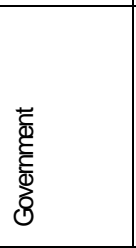 & $\begin{array}{l}\text { Government refers to the legislators, administrators, and arbitrators in the administrative } \\
\text { bureaucracy who control a state at a given time, and to the system of government by which } \\
\text { they are organized (Oxford dictionary, 2010). Government is the means by which state policy } \\
\text { is enforced, as well as the mechanism for determining the policy of the state. A form of } \\
\text { government, or form of state governance, refers to the set of political institutions by which a } \\
\text { government of a state is organized. In this framework we considered government as the } \\
\text { important stakeholder that affect the performance of the organizations by making and } \\
\text { performing and controlling the policies and decisions }\end{array}$ & $\begin{array}{l}\text { Bell (2002), Bhatnagar (2003), Adelman \& Yeldan (1999), Saich (2004), } \\
\text { Albareda et al. (2008) }\end{array}$ \\
\hline
\end{tabular}

Research article

CCIndian Society for Education and Environment (iSee)
"Business intelligence" http://www.indjst.org
Vol. 5 No. 6 (June 2012)

ISSN: 0974- 6846

(O) 


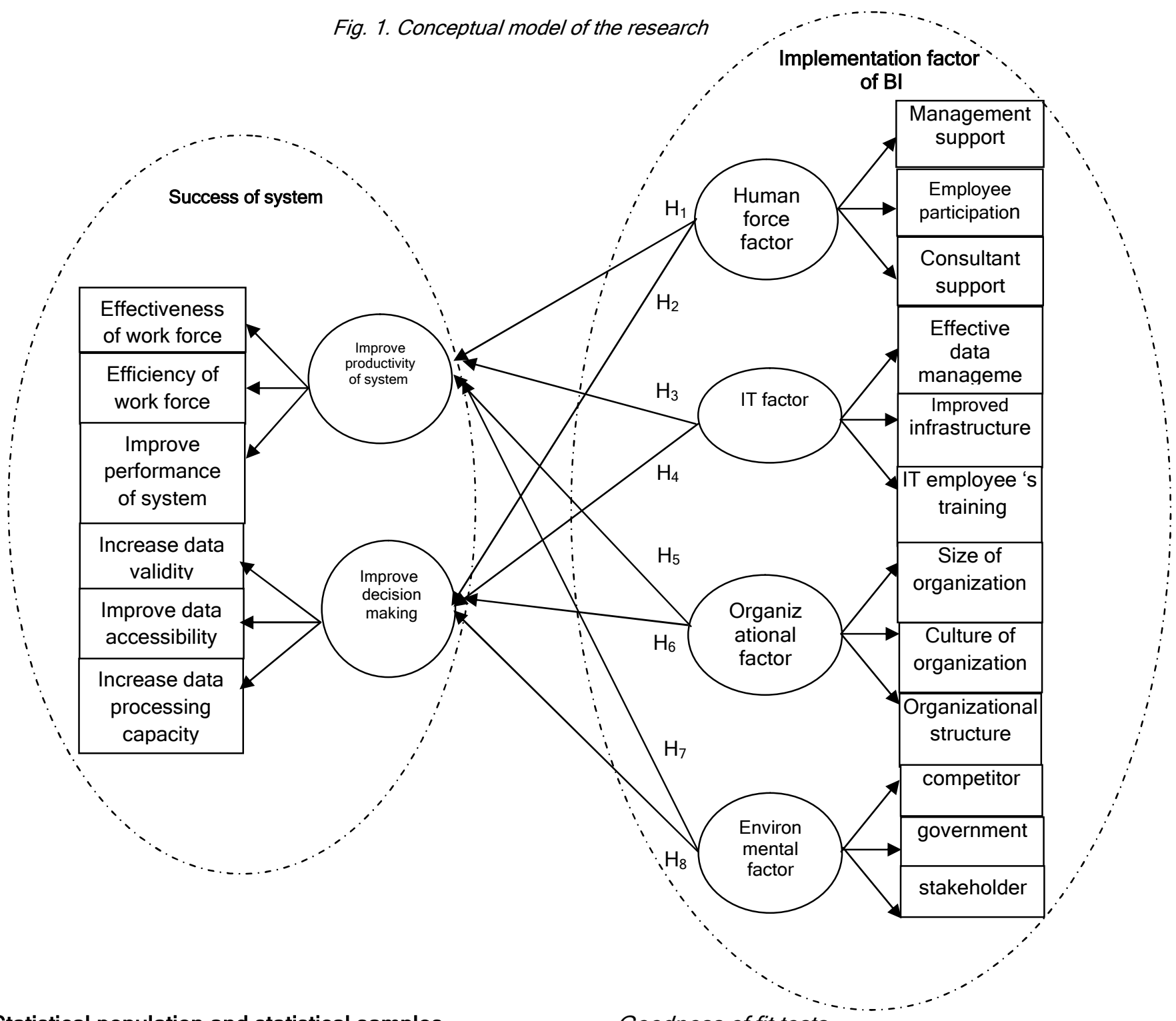

\section{Statistical population and statistical samples}

The data were collected from employees in Nano's comanies in Iran. All respondents were full- time employees and volunteered to participate in the study. Total number of established Nano's companies according to the report of Nano staff of technological cooperation office of presidency of Iran is about 30 companies. 245 questionnaires were delivered to employees by a researcher and 210 useful questionnaires were returned. Usable questionnaires entered into Excel datasheet and analyzed with the use of SPSS 17 and Lisrel 8.54. We computed our samples based on Morgan's table. Male employees accounted for $64.3 \%$ of the total participants, while female employees accounted for $35.7 \%$. From 210 respondents, 131 people with bachelor degree, 64 people with master degree, and 15 people have phd degree. This is while the age of 41 of these people were $20-30,82$ people between 31- 40, 73 between $41-50,14$ people between 51 - 60 years old.

Research article

(C)Indian Society for Education and Environment (iSee)
Goodness of fit tests

Structural Equation Modeling (SEM) with LISREL 8.54 (Petroutsatou \& Lambropoulos, 2007) was used to test and analyze the hypothesized relationships of the research model. SEM aims to examine the inter-related relationships simultaneously between a set of posited constructs, one measures each of those or more observed items (measures). The goodness of fit of a statistical model describes how well it fits a set of observations. Measures of goodness of fit typically summarize the discrepancy between observed values and the values expected under the model in question. Such measures can be used in statistical hypothesis testing. . Generally, in this study to assess the goodness

\section{Table 2. Reliability of the study}

\begin{tabular}{|l|c|}
\hline \multicolumn{1}{|c|}{ Questions } & Cronbach's Alpha \\
\hline Critical success factors & 0.91 \\
\hline System success & 0.89 \\
\hline All & 0.91 \\
\hline ind igence" & M.Negar et al. \\
indjst.org & Indian J.Sci.Technol.
\end{tabular}


Table 3. The result of Goodness of Fit Tests

\begin{tabular}{|c|c|c|c|c|c|c|c|}
\hline $\mathrm{X}^{2} / \mathrm{df}$ & $\begin{array}{c}\text { Root Mean } \\
\text { square } \\
\text { Residual } \\
\text { (RMR) }\end{array}$ & $\begin{array}{c}\text { Goodness of } \\
\text { Fit Index } \\
\text { (GFI) }\end{array}$ & $\begin{array}{c}\text { Adjusted } \\
\text { Goodness } \\
\text { of Fit Index }\end{array}$ & $\begin{array}{c}\text { Root Mean } \\
\text { Square Error of } \\
\text { Approximation }\end{array}$ & $\begin{array}{c}\text { Normed Fit } \\
\text { Index (NFI) }\end{array}$ & $\begin{array}{c}\text { Non- } \\
\text { Normed } \\
\text { Fit Index }\end{array}$ & $\begin{array}{c}\text { Comparative Fit Index } \\
\text { (CFI) }\end{array}$ \\
\hline 2.67 & 0.049 & 0.91 & 0.92 & 0.070 & 0.96 & 0.94 & 0.94 \\
\hline
\end{tabular}

Table 4. Factor loading and the corresponding t-values of indicators in the measurement model

\begin{tabular}{|c|c|c|}
\hline Construct / Indicator & Factor loading & t- value \\
\hline \multicolumn{3}{|c|}{ Human force factors } \\
\hline SUPPORT & 0.42 & 10.59 \\
\hline PARTER & 0.59 & 14.83 \\
\hline CONSUL & 0.65 & 15.31 \\
\hline \multicolumn{3}{|c|}{ IT factors } \\
\hline DATA & 0.41 & 8.93 \\
\hline INFRA & 0.10 & 2.49 \\
\hline TRAINING & 0.16 & 4.24 \\
\hline \multicolumn{3}{|c|}{ Organizational factors } \\
\hline SIZE & 0.17 & 2.69 \\
\hline CULTUR & 0.21 & 4.38 \\
\hline STRUCTUR & 0.38 & 6.80 \\
\hline \multicolumn{3}{|c|}{ Environmental factors } \\
\hline COMPETAT & 0.63 & 11.07 \\
\hline GOVERNME & 0.53 & 11.07 \\
\hline STOCKHOL & 0.68 & 12.41 \\
\hline \multicolumn{3}{|c|}{ Improvement of productivity } \\
\hline EFFECTIVE & 0.61 & 5.61 \\
\hline EFFICIENCE & 0.56 & 6.71 \\
\hline SYSTEM & 0.61 & 7.22 \\
\hline \multicolumn{3}{|c|}{ Improvement of decision making } \\
\hline RELEABIL & 0.46 & 3.66 \\
\hline ACCESS & 0.25 & 2.97 \\
\hline PROCESSI & 0.43 & 4.08 \\
\hline
\end{tabular}

of fit of the entire model measures such as $\mathrm{X} 2 / \mathrm{df}$, RMR, GFI, AGFI, RMSEA, NFI, NNFI, CFI has been used. The relative chi-square (chi-square/degree of freedom; $x^{2} / d f$ ), standardized root mean square residual (standardized RMSR), goodness-of-fit index (GFI), adjusted goodnessof-fit index (AGFI), normed fit index (NFI), and comparative fit index (CFI) were used as goodness-of-fit measures.

Due to the sensitivity of the chi-sqare test to sample size, the relative chi-square was used (it should be 3 o less for an acceptable model (Tomer \& Pugesek, 2003), Standardized RMSR should not be greater than 0.10 and

Table 5. Results of testing the hypotheses of the study using path analysis

\begin{tabular}{|c|c|c|c|c|c|}
\hline \multirow{2}{*}{\begin{tabular}{|c|} 
Hypotheses \\
1 \\
1
\end{tabular}} & \multicolumn{2}{|c|}{ Path } & \multirow{2}{*}{$\begin{array}{c}\text { Standardized estimated } \\
0.87\end{array}$} & \multirow{2}{*}{$\begin{array}{c}\text { The Significance of Parameters } \\
3.43\end{array}$} & \multirow{2}{*}{$\begin{array}{c}\text { Testing Hypotheses } \\
\text { Confirmed }\end{array}$} \\
\hline & HUM & PROD & & & \\
\hline 2 & HUM & DECIS & 0.54 & 5.42 & Confirmed \\
\hline 3 & INFO & PROD & 0.23 & 1.34 & rejected \\
\hline 4 & INFO & DECIS & 0.29 & 1.11 & rejected \\
\hline 5 & ORGA & PROD & 0.65 & 4.45 & Confirmed \\
\hline 6 & ORGA & DECIS & 0.78 & 4.88 & Confirmed \\
\hline 7 & ENVI & PROD & 0.52 & 6.32 & confirmed \\
\hline 8 & ENVI & DECIS & 0.67 & 5.77 & Confirmed \\
\hline
\end{tabular}

.GFI, AGFI, NFI, and CFI should exceed 0.90 to be acceptable (Hair et al., 2006). The rate of each index has come in the Table 3.

The measurement model with all six constructs was using confirmatory factor analysis (Petroutsatou \& Lambropoulos, 2007). Table 4 presents factor loading and the corresponding t-values of indicators in the measurement model. All loading exceed 0.4 and each indicator is significant at 0.05 levels. The measurement model exhibited a good level of model fit.

\section{Testing hypotheses}

The specification of the model consists of the translation of the verbal hypotheses into a series of equations previously represented in the form of a causal or a path diagram. The path diagram shows the causal relationships among all variables in the system. It should be based upon a priori knowledge of such relationships which are ultimately related to previous experience or theoretical basis (Fox, 2003). Thus, the path diagram represents the working hypothesis about the causal relationships among variables.

Fig. $2 \& 3$ shows structural model of the study for confirming first secondary hypotheses of the study in standard estimation state and structural model to test the research hypotheses in a meaningful parameter.

Based on analysis done using path analysis, results of testing hypotheses of the study can be seen in Table 5 . Standard estimation test and significance value in confirming or rejecting considered hypotheses (significance of hypotheses) has been used.

\section{Discussion and conclusions}

In terms of the literature of Critical Success Factors and mainly in Yeoh articles $(2008,2009,2011)$ about business intelligence, some of critical success factors such as management commitment, consultant support, constant education, employee involvement and proper infrastructure were stressed. But in this study researchers emphasize on environmental factor that is the 
Vol. 5 No. 6 (June 2012)

ISSN: 0974- 6846

Fig. 2. Structural model to test the research hypotheses in standard estimation state

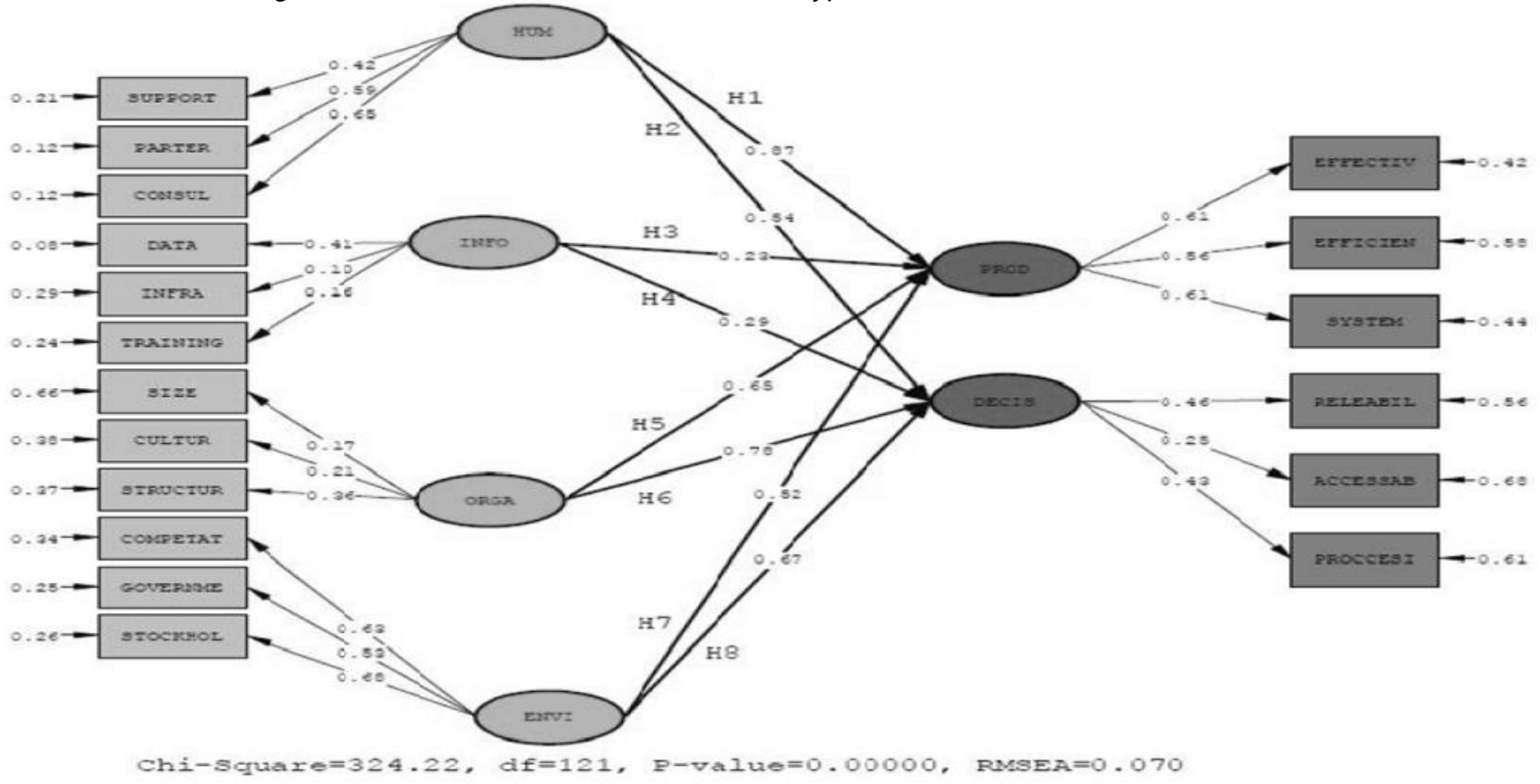

Fig. 3. Structural model to test the research hypotheses in a meaningful parameter

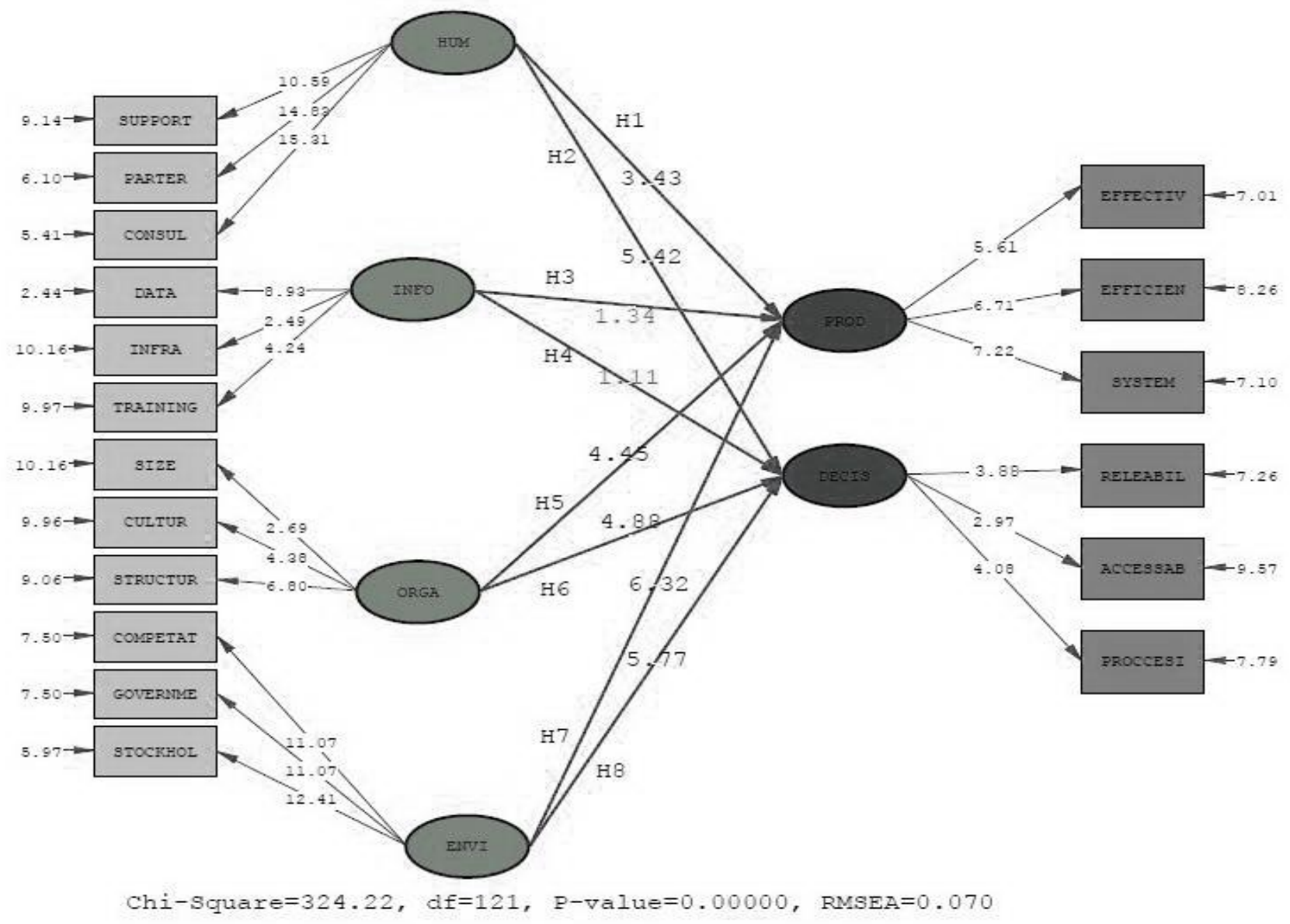


requirement of any industry and business (Porter, 1979) and combine it with previous factors with some modification. Many similar researches independently have been done around the role of competitor and benchmarking in implementation of knowledge management like Akhavan et al. (2006) or the contribution of stakeholder (customers, buyer, suppliers, employee and public) in business intelligence model (Simmers, 2004). The research result is divisible in 3 parts which would be mentioned as follow.

In the first place, in this research it is shown a comprehensive model about $\mathrm{BI}$ and its role in integrating knowledge obtained from inside and outside of organizations, regarding to the use of IT-based systems with humans factors especially culture and competition based approach of people. Alongside of this, the model describes the importance of this integration towards using $\mathrm{BI}$ for reaching the success of systems which copes with the survival of each organization in context of learning organization. In this case, the model can use for all leading organization in establishing newest $\mathrm{BI}$ systems in particular companies which provide products of NANO.

Secondly, the hypotheses presented in this study were based on the conceptual model. From 8 hypotheses, 6 ones were confirmed. These were associated with people, organization and environment factors which had considerable effect on improving decision and productivity of organization. They showed that NANO's companies in Iran can prepare excellent conditions to step towards using $\mathrm{BI}$ systems, irrespective of IT infrastructures. About this, the results illustrated that $\mathrm{H} 3$ and $\mathrm{H} 4$ hypotheses are rejected. In another word, lack of adequate bandwidth, low speed of the internet and lack of access to all market knowledge because of being unreliability in internet-based systems would create likely problems which can endanger success of $\mathrm{Bl}$ systems. Therefore, it is better that authorities try to improve IT infrastructures at least in Knowledge-founded organizations in order to prepare good occasions towards providing the productions in markets and sharing the knowledge with other companies.

Finally, Since the system success depends on Human, IT, Structural and Environmental factors, So it is better that researchers have been more centralization on these factors to improve performance and effectiveness and efficiency of system which have direct relation to productivity and can reinforce data processing and accessibility and validity of data to improve the decision making capacity of organizations.

According to the implementation of this model in NANO technology area and obtaining valid results, it is recommended to have greater investigation in other industry and era and providing required infrastructure in order to perform business intelligence system. Therefore, it is suggested to empower the cooperative atmosphere between management and employees and emphasize on the supportive role of consultant and invest in training of the employee and improve the effective management of data and adapt the size and structure with the innovative and learning culture of the organizations and better observation of the effect of governmental regulation and support and being tender to the movement of the competitors and considerate the needs of the stakeholders in select and implementing high technologies systems like business intelligence.

\section{References}

1. Abu Ali AN and Abu Addose HY (2010) Data warehouse critical success factors. Europ. J. scientific Res. 42(2), 326 - 335.

2. Adelman I and Yeldan AE (1999) The role of government in economic development. Department of agricultural and resource economics and policy division of agricultural and natural resources university of California at Berkeley.

3. Akhavan $P$ and Jafari $M$ (2006) Critical success factor's of knowledge management systems: multi case analysis. Europ. Business Rev. J. 18(2), 97-113.

4. Akhavan $P$ et al (2010) The challenges of knowledge management portals application and implementation : A Iranian organization case study. Int/. J. Industrial Engg. Computations.1, 79-93.

5. Albareda L et al (2008) The changing role of governments in corporate social responsibility: drivers and responses. Business ethics. Eur. Rev. 17(4), 347363.

6. Al Busaidi KA et al (2010) Sharing knowledge to knowledge management system: Examining the motivator and the benefits in a Omani organization. $J$. Organizational KM. 928-935

7. Al - Hudhaif SA (2010) Measuring quality of information system services in manufacturing organization in Riyadh. JKAU : Econ \& Adm, 24(1), 151-171

8. APQC (1999) Knowledge management: executive summary. Consortium benchmarking study best practice report, American productivity \& Quality center : www.apqc.org

9. Arnott D (2008) Success factors for data warehouse and $\mathrm{BI}$ systems. Center for decision support and enterprise systems research, Monash university, Melbourne, Australia. 55-65

10.Arnott D and Pervan G (2005) A critical analysis of DSS research. J.Information Technol. 20(2), 67 - 87.

11.Bell DVJ (2002) The role of government in advancing corporate sustainability. Sustainable Enterprise Acad. York University.

12. Bhatti TR (2005) CSF's for the implementation of enterprise resource planning. $2^{\text {nd }}$ Int.Conf. Innovation in Information Technol. 21-34

13.Bhatnagar S (2003) Role of government: as an enabler, regulator, and provider of ICT based services. Asian forum on ICT policies \& e - strategies, Kuala lumpur : www.Apdip.net/asian- forum
Research article

CIndian Society for Education and Environment (iSee)
"Business intelligence" http://www.indjst.org
M.Negar et al. Indian J.Sci.Technol. 
14. Bozbura FT (2007) Knowledge management practices in Turkish SME's. J. Enterprise Information. 2(2), 209221.

15.Buckman R (1999) Collaborative knowledge. Human resource planning. 22(1), 22-23.

16. Chan LK et al (2011) A SOA - driven BI architecture. Communication of the IBIMA. pp: 8.

17.Chang $\mathrm{MH}$ and Harrington JE (2000) Centralization vs. decentralization in a multi - unit organization: Computational model of a retail chain as a multi agent adaptive system. Management Sci. 46(11), 1427-1440.

18.Chong SC (2006) Knowledge management critical success factors: a comparison pf perceived importance versus implementation in Malaysian ICT companies. The learning organization. 13, 230-256.

19. Davenport TH et al ( 2007) The Dark Side of Customer Analytics. Harvard Business Review .85 (5), 37-48

20.Davis FD (1989) Perceived usefulness perceived ease of use, User acceptance of IT. MIS Quarterly. 13, 319340.

21.Day $\mathrm{J}$ and Wendler $\mathrm{J}$ (1998) Best practice and beyond knowledge strategies. McKinsey Quarterly. 1, 19-25.

22.Dehenry $\mathrm{F}$ (2009) Accessing $\mathrm{BI}$ readiness. FMT systems Inc., as viewed on $21^{\text {st }}$ August

23.Drew SAW (1997) From knowledge to action: the impact of benchmarking on organizational performance. Long range planning. 30(3), 427-441.

24.Du Plessis M (2007) Knowledge management: What makes complex implementations successful?. J. knowledge management.11(2), 91-101

25.Eckerson W (2005) Dashboard or scorecard: which should you use?. TDWI Case studies \& solutions Elect. Newsletter. Jan 11

26. Ellis TS and Webster RL (1998) Innovativeness of IS managers toward telecommunicating: A structural equation model. J. Computer. IS. 39(3),161 -168

27.ESCC UA (2009) Overview: bi reference guide. U.S army enterprise solutions competency center.1-120

28.Garrity EJ and Sanders GL (1998) Information systems success measurement. Hershey,USA: Idea group publishing. 1-184

29. Greco I (1999) Knowledge is power. J. Business Strategy. 20(2), 18 - 22.

30.Gremillion LL (1984) Organization size and information system use:and empirical study. J. Management Information sys. (1)2, 4-17.

31. Hair JF et al (2006) Multivariative data analysis $\left(6^{\text {th }}\right.$ Edn), Pearson prentice hall, New Jercy.

32. Hassanali $F(2002$ ) Critical success factors of KM ", www.kmadvantage.com/docs/km-articles/CriticalSuccess-Factors-of-Knowledgemanagement.pdf

33. Howson, C (2000) Successful BI : secrets to making BI , a killer App ", McGraw. Hill companies.

34. Hung YH and Chou SC (2005) On constructing a Knowledge management pyramid model. 2005 IEEE Intl. Conf. information Reuse \& Integration. 1-6
35. Indeje WG et al (2010) Organizational culture and information systems implementation: A structuration theory perspective. Sprouts, working papers on Information sys. 10(27)

36. Katsoulakos T and Katsoulacos Y (2007) Strategic management, Corporate responsibility and stakeholder management integrating corporate responsibility principles and stakeholder approaches into main stream strategy: a stakeholder - oriented and integrative strategic management framework. Corporate Governance. 7(4), 355-369.

37. Knightsbridge Inc (2006) Getting smart about BI: best practices deliver real value. Business week res. serv.

38. Kumarasinghe $S$ et al (2003) Influence of corporate culture, structure and strategy on organizational performance: an empirical study of business organizations in Sri Lanka. Japan. J. Administ. Sci. 16(3), 227-242.

39. Kumar R (2005) Research methodology: a step by step guide for beginners. Sage publication.1-418

40.Lawler EE (1999) Rethinking organization size. www.fing.edu.uy/tecnoinf/cursos/.../rethinkingorganiza tionsize.pdf

41.Liebowitz J (1999) Key ingredients to the success of an organization's knowledge management strategy. Knowledge and process management. 6(1), 37-40.

42. Markarian I et al (2007) CSF deploying pervasive BI. USA: Informatica, Teradata, Microstrategy.1-18

43.McDermott $R$ and O'Dell C (2001) Overcoming cultural barriers to sharing knowledge. J.KM. 5(1), 76-85.

44. Melone NP (1990) Theoretical assessment of the user satisfaction construct in IS research. Manage. Sci. 36(1), 76 - 91.

45. Moffett $S$ et al (2003) An empirical analysis of knowledge management applications. J. KM. 23(3), 626.

46. Moore GC and Benbasat I (1991) Development of an instrument to measure perceptions of adopting an IT innovation. IS Res. 2(3), 192-222.

47. Murray D (2009) 7 principles for implementing high value $\mathrm{BI}$ on a budjet. Taleau software.

48. Nadeem $\mathrm{M}$ et al (2003) Application of $\mathrm{BI}$ in banks (Pakistan) shared Zulifqar Ali Bhutto institute pf science and technology.

49. O' dell C and Grayson I (1998) If only we know what we know : identification and transfer of internal best practices. California Managnt. Rev.40(3),154-165.

50. Olszak CM and Ziemba E (2003) BI system in the holistic infrastructure development supporting decision making in organization. Interdisciplinary J. Information, knowledge \& Manage. 1,47-58

51.Oxford dictionary (2010) Government. www.oxforddictionaries.com.

52.Petroutsatou C and Lambropoulos S (2007) Early estimating of road tunnel construction cost. Technika Chronika, Technical chamber of Greece, I. 1(2), 99110.
Research article

(C)Indian Society for Education and Environment (iSee)
"Business intelligence"

http://www.indjst.org
M.Negar et al. Indian J.Sci.Technol. 
53.Pitt LF et al (1995) Service quality: a measure of IS effectiveness. MIS Quaterly. pp: 173 - 186.

54.Platon AS (2009) Introduction to $\mathrm{BI}$ and data warehouse. Copenhagen, Denmark, Platon AS.

55. Reimann BC (1974) Dimensions of structure in effective organizations: some empirical evidence. Acad. Manage. J. 17,693-708.

56. Rud P (2009) BI success factor: tools for aligning your business in the global economy, John wiley \& sons, Inc. 1-283

57.Ryan SD and Prybutok VR (2001) Factors affecting knowledge management technologies: a discriminative approach. J. Compt. Information Sys .41(3), 31- 37.

58.Saich T (2004) The changing role of government: background note for the world bank report on china's $11^{\text {th }}$ five year plan. Kennedy school of government, Harvard university.

59. Salegro A et als.(2008) Application of BI methods for personalizing tourist. WSEAS transaction on system, 7(10), $1176-1185$

60.Saraph JV et al (1989) An instrument for measuring the critical factors of quality management. Decision sci. $20,810-829$.

61. Sayal AH et al (2000) An empirical investigation of use of IT among small and business organization: A Bruneian scenario. Elect. J. Information Sys. Developing Countries. 2(7), 1-17.

62.Schneider B (1975) Organizational climate: an essay personnel psychology. 28, 447-479.

63.Skyrme D and Amidon D (1997) The knowledge agenda. J.KM. 1(1), 27-37.

64.Sharaki and Esmaeeil poor (2010) Apllication of BI system in order to support sugar market. Proce. Conf. Organiz. Intelligence, $\mathrm{BI}$ in Iran. 1-9

65.Simmers CA (2004) A stakeholder model of business intelligence. Hicss. Proc. $37^{\text {th }}$ Annual Hawaii Int. Conf. Sys. Sci. 8(80), pp: 223b.

66. Tocan MC (2009) Critical factors to KM implementation. Int. Conf. Econ. \& Administ. University of Bucharest, Romania.

67. Tomer A and Pugesek BH (2003) Guidelines for the implementation and publication of structural equation models in Pugesek BH,Tomer A,Von eye, A.(Eds), structural equation modeling : application in ecological and evolutionary biology, Cambridge university press, Cambridge.

68.Valimohammadi C (2010) Identification and prioritization of CSF's of knowledge management in Iranian SME's: an expert's view. Afr. J. Bus. Manage. 4(6), 915-924.

69. Vesset D (2005) Worldwide DW tools 2005 vendor shares. Technical report, IDC: www.IDC.com.

70.Vodappalli NK (2009) CSF of BI implementation .Master's thesis report, IT University Copenhagen.
71.Watson H and Haley B (1997) Data warehousing: a framework and survey of current practice. J. Data warehousing. 2(1), 10-17.

72. Watson $\mathrm{H}$ and Ariyachandra T (2005) Data warehouse Architectures: Factors in the selection decision and success of architectures. www.terry.uga.edu.

73. Wild RH et al (2002) A framework for e-learning as a tool for Knowledge management. Indust. Manage. \& Data sys. 102(7\&64), 371-380.

74. Wixom BH and Watson H (2001) An empirical investigation of the factors affecting data warehousing success. MIS quarterly. 25(1),17-41.

75.Wong $\mathrm{KY}$ et al (2005) Is equivalent to information technology?. Proc. $4^{\text {th }}$ Europ. Conf. Knowledge Managnt. Oxford Univ, Oxford. 989-997.

76. Xu H and Hwang M (2008) A structural model of deta warehousing success. Scholarship and professional work. Business paper. pp: 78.

77. Yarmohammadzadeh $p$ et al (2011) The analysis of relationship between organizational structure and IT : and the barriers to its establishment at the university of Isfahan from the faculty member's view points. Higher education studies. 1(1), 98-104

78. Yeoh W (2011) BI systems implementation: Testing a critical success factors framework in multiple cases. Intl. J. Business information sys. 8(2), 192-205

79. Yeoh, W et al (2008) Managing the implementation of business intelligence systems: a critical success factors framework, International Journal of Enterprise Information Systems, Vol. 4, No. 3, pp.79-94

80. Yin RK (2003a) Case study research: design and methods, Third edition, Sage publications, Thousand Oaks, London and New Dehli.

81.Zannetos ZS and Sertel MR (1970) Computerized management information systems and organizational structures, Massachusetts institute of technology, Cambridge, working paper.
"Business intelligence" http://www.indjst.org
M.Negar et al. Indian J.Sci.Technol. 